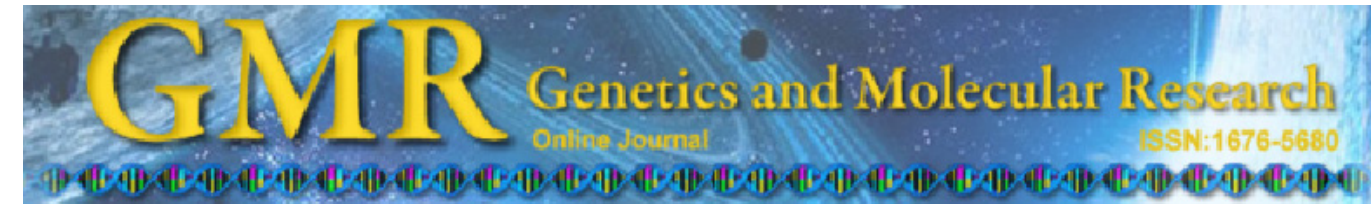

\title{
Molecular characterization of the Andean blackberry, Rubus glaucus, using SSR markers
}

\author{
M. Marulanda, A.M. López and M. Uribe \\ Laboratorio de Biotecnología Vegetal, Facultad de Ciencias Ambientales, \\ Universidad Tecnológica de Pereira, Pereira, Colombia \\ Corresponding author: M.L. Marulanda \\ E-mail:mlmarulanda@utp.edu.co
}

Genet. Mol. Res. 11 (1): 322-331 (2012)

Received July 11, 2011

Accepted September 15, 2011

Published February 10, 2012

DOI http://dx.doi.org/10.4238/2012.February.10.3

\begin{abstract}
The species Rubus glaucus, also known as the Andean or "Castilla" blackberry, is one of nine edible species of this genus that grow naturally in Central and South America. In Colombia, this species is the most important of all Rubus species for agricultural and commercial purposes. We used 20 SSRs developed for other Rubus species to characterize 44 Colombian $R$. glaucus genotypes, collected from eight different departments, and to look for molecular differences between thornless and thorny cultivated blackberries. Eighty-two bands were obtained from 28 loci. The genotypes were classified into eight populations, corresponding to collection sites. The mean number of polymorphic alleles per locus in all populations and genotypes ranged from 1.857 to 2.393. Samples collected from Valle del Cauca, Quindío, Caldas, and Risaralda departments had the highest heterozygosity values. The finding of exclusive bands from $R$. glaucus genotypes from Valle del Cauca, Quindío, and Caldas demonstrates genetic and molecular differentiation between thorny and thornless Andean blackberries.
\end{abstract}

Key words: Microsatellites; SSRs; Rubus glaucus; Colombia; Molecular characterization; Thornless blackberry 


\section{INTRODUCTION}

One of the most interesting characteristics present in several Rubus species is the absence of thorns. Several commercial varieties, for example, "Chester Thornless", "Thornfree", and "Thornless Evergreen", are thornless genotypes from the United States. This one-gene characteristic, controlled by a recessive gene, has been extensively studied in Europe and the United States (Jennings and Ingram, 1983; Hall, 1990; Skirvin et al., 2009).

Among cultivated Colombian blackberry genotypes, several do not have thorns but show the same productivity and fruit size as the thorny genotypes generally cultivated throughout the country. However, given their interesting phenotypic characteristics and much lower production costs, farmers have mass-propagated these genotypes commonly referred to as "thornless" blackberries, using vegetative methods. Marulanda et al. (2007) found two possible origins of thornless Rubus glaucus materials: one in the department of Risaralda and the other in the department of Quindío.

However, other sources of thornless $R$. glaucus could exist. Blackberries belong to the family Rosaceae, genus Rubus, subgenus Eubatus Focke. Commercial Rubus species include those with red berries known as "raspberries" ( $R$. idaeus L.) and those with black berries known as "blackberries", such as the species $R$. occidentalis L. cultivated in the northern hemisphere, especially Europe and North America. Andean blackberries are regarded as "blackberries" and belong to several species that grow in both Central and South America (Thompson, 1997).

Previous study carried out by Marulanda et al. (2007) and Marulanda and López (2009) on the genetic diversity of Colombian blackberries identified high phenotypic and molecular plasticity in the $R$. glaucus species known as the "Castilla" blackberry in Colombia's central Andean area. Other wild Rubus species present in the Andean region are found near farms where the "Castilla" blackberry is commercially grown. These plants were also submitted to morphological, agronomic, and molecular characterizations using amplified fragment length polymorphism (AFLP) and simple sequence repeat (SSR) molecular markers (Marulanda and López, 2009).

This study identified the molecular differences between thorny and thornless $R$. glaucus of wild and cultivated genotypes from eight different blackberry-producing regions of Colombia using 20 microsatellite sequences developed for other Rubus species.

\section{MATERIAL AND METHODS}

\section{Study material}

Forty-four Rubus genotypes, both cultivated and non-cultivated, were collected in eight departments of Colombia's Andean region: Cundinamarca, Santander, Valle del Cauca, Antioquia, Huila, Caldas, Quindío, and Risaralda. The materials included thorny and thornless $R$. glaucus genotypes plus the wild species $R$. urticifolius (Table 1). 
Table 1. Rubus species and genotypes collected in eight different regions of Colombia.

\begin{tabular}{|c|c|c|c|c|}
\hline Number & Code & Species & Characteristics & Collection area \\
\hline 1 & CVM1 & R. glaucus & Thorny & Cundinamarca \\
\hline 2 & CVM2 & R. glaucus & Thorny & Cundinamarca \\
\hline 3 & CVM3 & R. glaucus & Thorny & Cundinamarca \\
\hline 4 & CVM4 & R. glaucus & Thorny & Cundinamarca \\
\hline 5 & CVM6 & R. glaucus & Thorny & Santander \\
\hline 6 & CVM7 & R. glaucus & Thornless & Santander \\
\hline 7 & CVM8 & R. glaucus & Thorny & Santander \\
\hline 8 & CVM9 & R. glaucus & Thorny & Santander \\
\hline 9 & CVM10 & R. glaucus & Thorny & Valle del Cauca \\
\hline 10 & CVM11 & R. idaeus & Thornless & Valle del Cauca \\
\hline 11 & CVM12 & R. glaucus & Thorny & Valle del Cauca \\
\hline 12 & CVM13 & R. glaucus & Thorny & Valle del Cauca \\
\hline 13 & CVM15 & R. glaucus & Thorny & Antioquia \\
\hline 14 & CVM16 & R. glaucus & Thorny & Antioquia \\
\hline 15 & CVM17 & R. glaucus & Thorny & Antioquia \\
\hline 16 & CVM18 & R. glaucus & Thornless & Antioquia \\
\hline 17 & CVM19 & R. glaucus & Thorny & Antioquia \\
\hline 18 & CVM20 & R. glaucus & Thorny & Antioquia \\
\hline 19 & CVM22 & R. glaucus & Thorny & Huila \\
\hline 20 & CVM23 & R. glaucus & Thorny & Huila \\
\hline 21 & CVM24 & R. glaucus & Thorny & Huila \\
\hline 22 & CVM25 & R. glaucus & Thorny & Huila \\
\hline 23 & CVM26 & R. glaucus & Thorny & Huila \\
\hline 24 & CVM27 & R. glaucus & Thorny & Huila \\
\hline 25 & CVM28 & R. glaucus & Thorny & Huila \\
\hline 26 & CVM & R. glaucus & Wild & Caldas \\
\hline 27 & CVMA & R. glaucus & Thornless & Risaralda \\
\hline 28 & CVMB & R. glaucus & Thorny & Quindío \\
\hline 29 & CVMC & R. glaucus & Thornless & Quindío \\
\hline 30 & CVMD & R. glaucus & Thorny & Risaralda \\
\hline 31 & CVME & R. glaucus & Thorny & Caldas \\
\hline 32 & 95 & R. glaucus & Wild & Quindío \\
\hline 33 & 107 & R. urticifolius & Wild & Quindío \\
\hline 34 & 106 & R. urticifolius & Wild & Quindío \\
\hline 35 & 97 & R. glaucus & Wild & Quindío \\
\hline 36 & 86 & R. glaucus & Wild & Quindío \\
\hline 37 & 22 & $R$. glaucus & Thorny & Caldas \\
\hline 38 & 37 & R. urticifolius & Wild & Caldas \\
\hline 39 & 44 & R. urticifolius & Wild & Risaralda \\
\hline 40 & MSA1 & R. glaucus & Thornless & Risaralda \\
\hline 41 & MSA2 & R. glaucus & Thornless & Risaralda \\
\hline 42 & MSA3 & R. glaucus & Thornless & Quindío \\
\hline 43 & MSA4 & R. glaucus & Thornless & Quindío \\
\hline 44 & MSA5 & R. glaucus & Thornless & Caldas \\
\hline
\end{tabular}

\section{DNA isolation and fragment analysis}

Samples were collected in silica gel, placed in plastic bags, and transported to the Biotechnology Laboratory of the Universidad Tecnológica de Pereira. DNA was isolated using the Plant DNAeasy Miniprep kit (QIAGEN ${ }^{\circledR}$ ), following manufacturer instructions. Several samples did not show any DNA after the isolation procedure, so it was necessary to reprocess these samples following the Doyle and Doyle (1990) protocol. In all cases, samples were purified using the protocol described by Castillo (2006).

Twenty microsatellite sequences that belong to other Rubus species native to Europe, North America, and Asia were used for DNA amplification (Table 2). These included nine SSR markers developed by Castillo (2006), eight developed by Graham et al. (2002, 2004), and three developed by Amsellem et al. (2001).

Amplification reactions were carried out in a total volume of $12.5 \mu \mathrm{L}$, with $20 \mathrm{ng}$ 
DNA, $2 \mu \mathrm{M}$ of each primer, $200 \mu \mathrm{M}$ of each nucleotide, $1 \%$ buffer $(10 \mathrm{mM}$ Tris-HCl, $\mathrm{pH} 8.3$, $50 \mathrm{mM} \mathrm{KCl}, 1.5 \mathrm{mM} \mathrm{MgCl}_{2}$ ), and $0.5 \mathrm{U}$ Taq DNA polymerase. The amplification profile was 30 cycles at $94^{\circ} \mathrm{C}$ for $1 \mathrm{~min}$, annealing temperature for $1 \mathrm{~min}$, and $72^{\circ} \mathrm{C}$ for $1 \mathrm{~min}$, with a final extension at $72^{\circ} \mathrm{C}$ for $10 \mathrm{~min}$.

\section{Data processing}

The number of loci, the number of alleles per locus $\left(N_{\mathrm{A}}\right)$, and the expected $\left(H_{\mathrm{E}}\right)$ and observed $\left(H_{\mathrm{O}}\right)$ heterozygosities were determined using GenAlEx 6.1 (Peakall and Smouse, 2006). Nei's genetic distance (1978) was calculated and a principal coordinates analysis was performed. The polymorphic information content (PIC) (Cordeiro et al., 2000) and the discrimination power (D) were calculated for each locus to compare the efficiency of markers in varietal identification (Tessier et al., 1999).

\section{RESULTS AND DISCUSSION}

A total of 28 loci were detected using the above mentioned microsatellite sequences, with $N_{\mathrm{A}}$ values ranging between 1 and 6 and a total of 82 bands. The 20 SSRs were found to be polymorphic for the 44 genotypes studied (Table 2). The number of alleles per population ranged between 52 and 67, where it was higher in the populations of Quindío, Valle del Cauca and Caldas (Table 3). Rare and low-frequency alleles were detected in the populations of Valle del Cauca, Caldas, Quindío, and Risaralda. Alleles with low frequencies $(\leq 25 \%)$ were found in Quindío, Caldas and Risaralda. The existence of Rubus genotypes with exclusive or private alleles at several of their loci is evidenced here, and observations indicate that some alleles are shared by all genotypes and populations (Table 4).

The populations of Valle del Cauca, Quindío, Caldas, and Risaralda also showed the highest $H_{\mathrm{E}}$ values $(0.501,0.493,0.470$, and 0.451$)$ (Table 3). The $H_{\mathrm{O}}$ values ranged from 0.728 in Quindío genotypes to 0.893 in the Huila population, with an average $H_{\mathrm{O}}$ of 0.825 . On the other hand, $H_{\mathrm{E}}$ values ranged from 0.413 in the Cundinamarca population to 0.501 in the Valle del Cauca population, with the highest values occurring in genotypes from Valle del Cauca, Quindío, Caldas, and Risaralda. The inbreeding coefficient $(\mathrm{F})$ for all loci and populations was -0.823 . This parameter represents the variability between individuals, also demonstrating genetic differentiation among them (Table 3 ).

Both $H_{\mathrm{E}}$ and $H_{\mathrm{O}}$ values of all microsatellites were high. In most cases, the $H_{\mathrm{O}}$ values were higher than the $H_{\mathrm{E}}$ values. The $H_{\mathrm{O}}$ values ranged from 0.056 with the RhM001 marker to 1.00 with the Rubus 259f, mRaCIRRIH3, Rubus 16a, RhM003, and RhM021 markers. Regarding the PIC and D parameters, the highest values were shown by microsatellites Rubus $76 \mathrm{~b}$, Rubus 105b, and Rubus 98d, followed by RiM017 and Rubus 259f (Table 2).

Similar results were reported by Castillo (2006), who used 12 SSRs to analyze an extensive collection of North American Rubus (raspberry) germplasm. Results indicated from 3 to 16 alleles per locus, with an average of eight alleles per locus and a total of 96 alleles. In the case of the blackberry samples, the same 12 pairs of primers amplified from 6 to 31 alleles per locus, with an average of 15 alleles per locus and a total of 177 alleles. More recently, Flores et al. (2010) isolated 12 microsatellites from SSR-enriched genomic libraries of Rubus idaeus. The best SSR loci, based on high $H_{\mathrm{O}}$ and $H_{\mathrm{E}}$, high PIC, and low F, were RiM019, RhM003 and RhM011. In this evaluation of Colombian Rubus materials, RhM003 was found to be one of the most informative. 


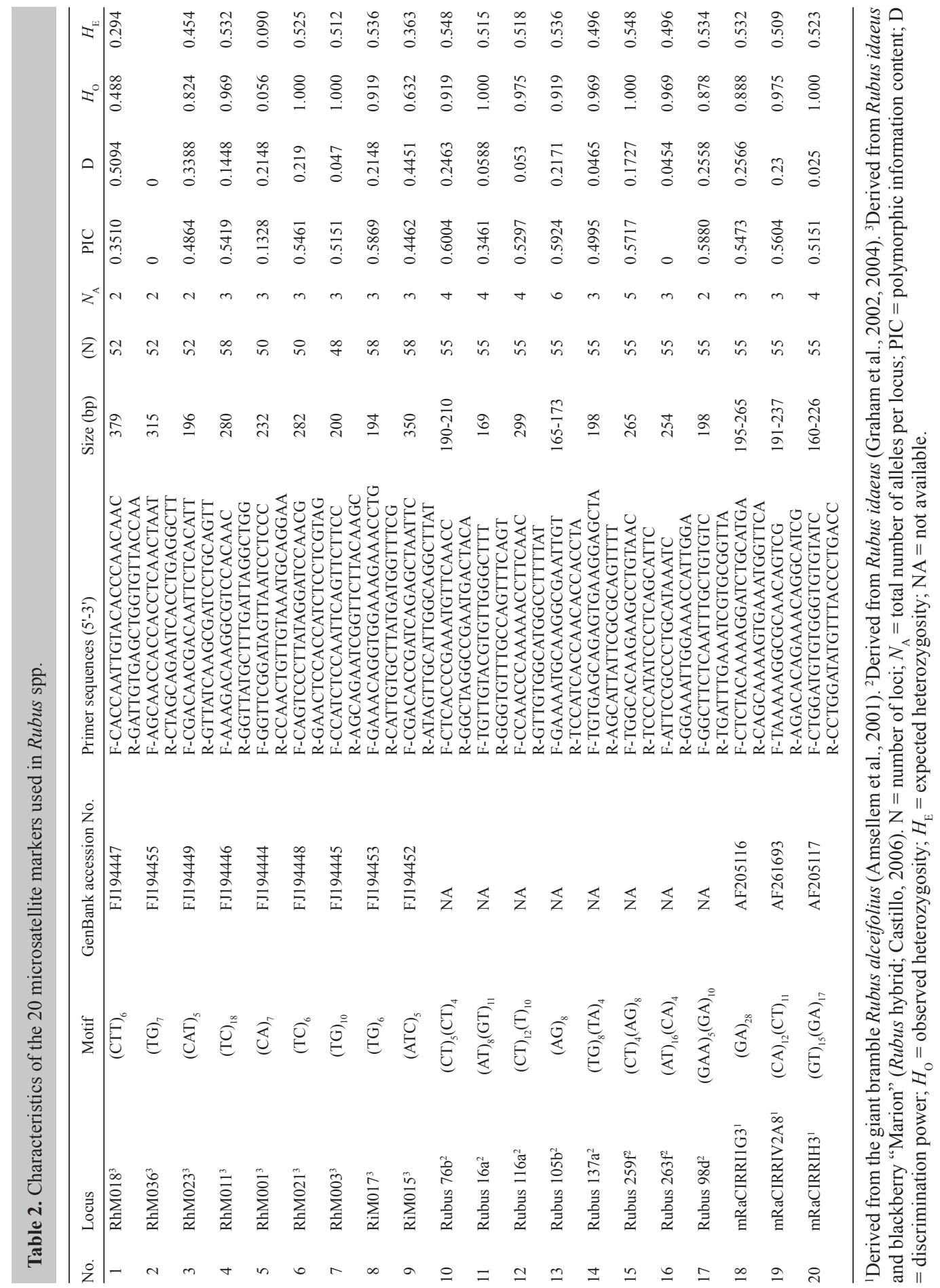


Table 3. Total values for allelic patterns and diversity parameters per population.

\begin{tabular}{lccccc}
\hline Population & $\mathrm{N}$ & $N_{\mathrm{A}}$ & $H_{\mathrm{O}}$ & $H_{\mathrm{E}}$ & $\mathrm{F}$ \\
\hline Cundinamarca & 52 & 1.857 & 0.813 & 0.413 & -0.969 \\
Santander & 52 & 1.857 & 0.857 & 0.429 & -1.000 \\
Valle del Cauca & 65 & 2.321 & 0.780 & 0.501 & -0.567 \\
Antioquia & 54 & 1.929 & 0.871 & 0.443 & -0.957 \\
Huila & 54 & 1.929 & 0.893 & 0.479 & -0.989 \\
Caldas & 63 & 2.250 & 0.771 & 0.493 & -0.654 \\
Quindío & 67 & 2.393 & 0.728 & 0.451 & -0.967 \\
Risaralda & 55 & 1.964 & 0.886 & 0.456 & -0.823 \\
Mean values & 57.75 & 2.063 & 0.825 & & \\
\hline
\end{tabular}

$\mathrm{N}=$ number of loci; $N_{\mathrm{A}}=$ number of alleles per locus; $H_{\mathrm{E}}=$ expected heterozygosity; $H_{\mathrm{O}}=$ observed heterozygosity; $\mathrm{F}=$ inbreeding coefficient.

Table 4. Summary of private alleles per population.

\begin{tabular}{llc}
\hline Sample & Population & Number of loci with private alleles \\
\hline CVM11 (Rubus idaeus) & Valle del Cauca & 9 \\
Wild CVM $($ R. glaucus $)$ & Caldas & 3 \\
95 (R. glaucus) & Quindío & 5 \\
107 (R. urticifolius) & Quindío & 5 \\
Thornless MSA3 (R. glaucus) & Quindío & 4 \\
Thornless MSA4 (R. glaucus) & Quindío & 4 \\
\hline
\end{tabular}

Sixty-one exclusive or rare alleles were obtained in the 28 loci, with the highest number of exclusive alleles (25) observed in genotypes from Valle del Cauca, followed by Quindío (24) and Caldas (12). Rubus idaeus genotype CVM11 from Valle del Cauca showed the highest number of exclusive alleles, followed by the wild genotypes $R$. glaucus 95 and $R$. urticifolius 107 from Quindío and the thornless genotypes MSA3 and MSA4, also collected in Quindío, together with CVM from Caldas. The loci in which the private alleles were detected are very important for genotype differentiation, particularly in the case of the thornless genotypes from Quindío because of their outstanding agricultural performance in ongoing field trials in several areas of Risaralda. Furthermore, this demonstrates the genetic differences between these genotypes as compared with the rest of the individuals analyzed (Table 4).

Figure 1 shows the grouping of the 44 genotypes studied. One large group, with $95 \%$ similarity, gathers most of the R. glaucus genotypes (both cultivated and wild) of the 8 populations. This group is then divided into two subgroups, with close to $98 \%$ similarity. The first subgroup gathers different individuals from the Departments of Cundinamarca, Antioquia, Santander, and Valle del Cauca, several with 100\% similarity. Genotypes MSA3-Quindío, MSA4-Quindío, CVMA-Risaralda, CVMB-Quindío, CVMC-Quindío, CVMD-Risaralda, 97-Quindío, MSA5-Caldas, and 22-Caldas are in the same subgroup, and based on agronomic evaluations carried out so far, they are considered to be the most promising blackberry materials and are therefore of great interest to this study.

The second subgroup shows $98 \%$ similarity and includes individuals from the Departments of Cundinamarca, Santander and Huila. This subgroup gathers individuals of MSA2Risaralda, CVM8-Santander and MSA1-Risaralda, with few differences between them. MSA1 and MSA2 from Risaralda are thornless cultivated $R$. glaucus genotypes. Individuals of 95-Quindío and 86-Quindío, wild R. glaucus species from the Department of Quindío, also belong to this subgroup, but their similarity is lower. 


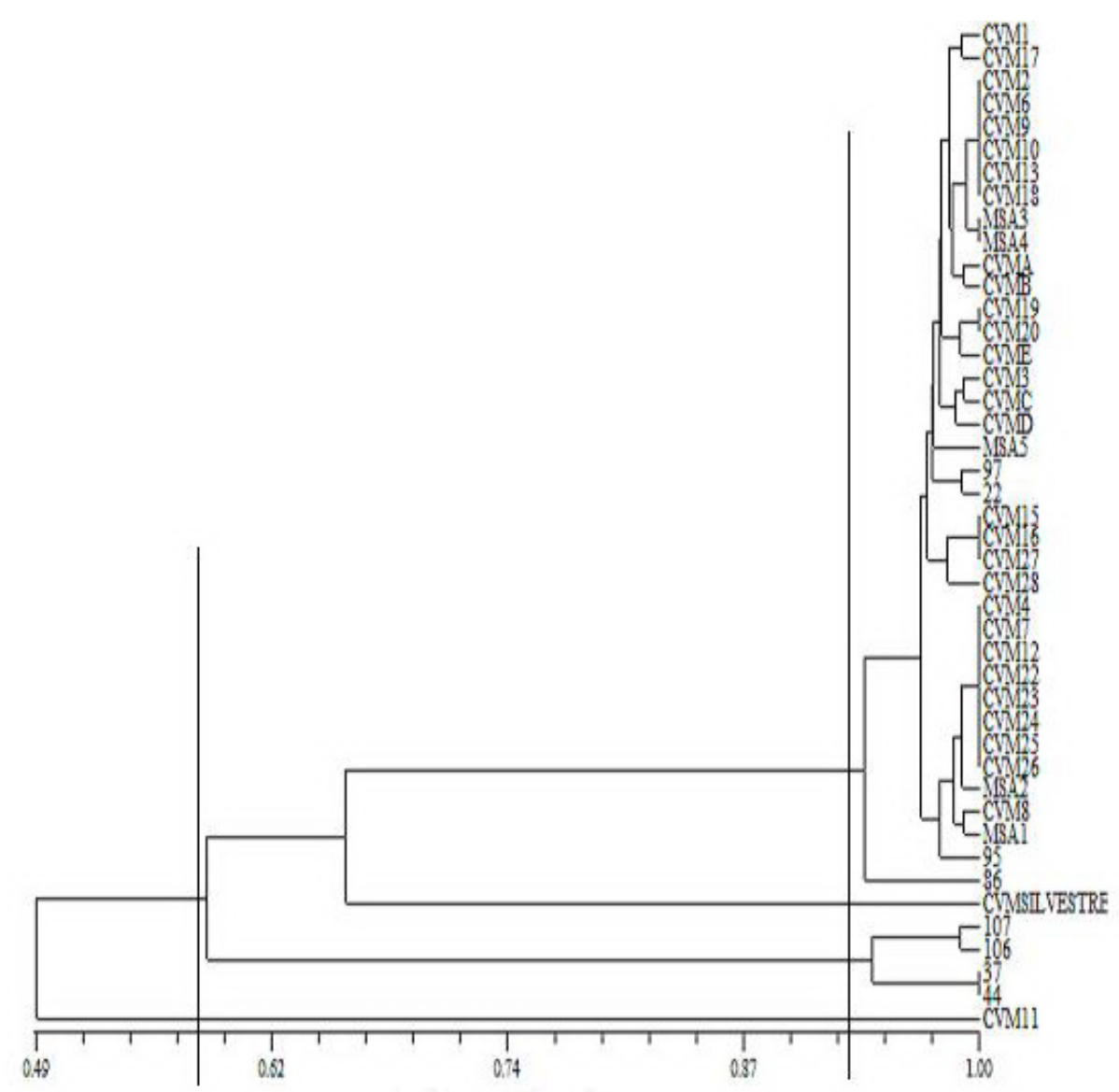

Figure 1. Dendrogram constructed with the Dice (1945) coefficient for Colombian Rubus genotypes.

Figure 2 presents the results of the principal coordinates analysis. There is no clear differentiation of genotypes based on collection sites; however, four groups can be distinguished: Group 1, which is characterized by materials broadly differing in origin and includes both cultivated and wild as well as thorny and thornless plants; Group 2, which includes both cultivated and thorny genotypes, mainly from Antioquia; Group 3, which is characterized by genotypes with little genetic distance between them and includes the highest number of genotypes from different sites of origin, most of them being thorny and thornless cultivated plants, and Group 4, located in the lower part of the figure, which includes genotypes, mainly from Quindío, with greater genetic distances, as well as the wild and cultivated thornless genotypes MSA3 and MSA4, collected in Quindío, the wild CVM genotype from Caldas, and finally genotype $R$. idaeus CVM11, a wild material from Valle del Cauca, which was found to differ from most of the other genotypes.

The proximity between thorny and thornless $R$. glaucus genotypes and the wild species $R$. urticifolius $(37,106,44)$ should be highlighted. The molecular proximity between the two species had already been described by Aguilar (2006) and Marulanda et al. (2007). 


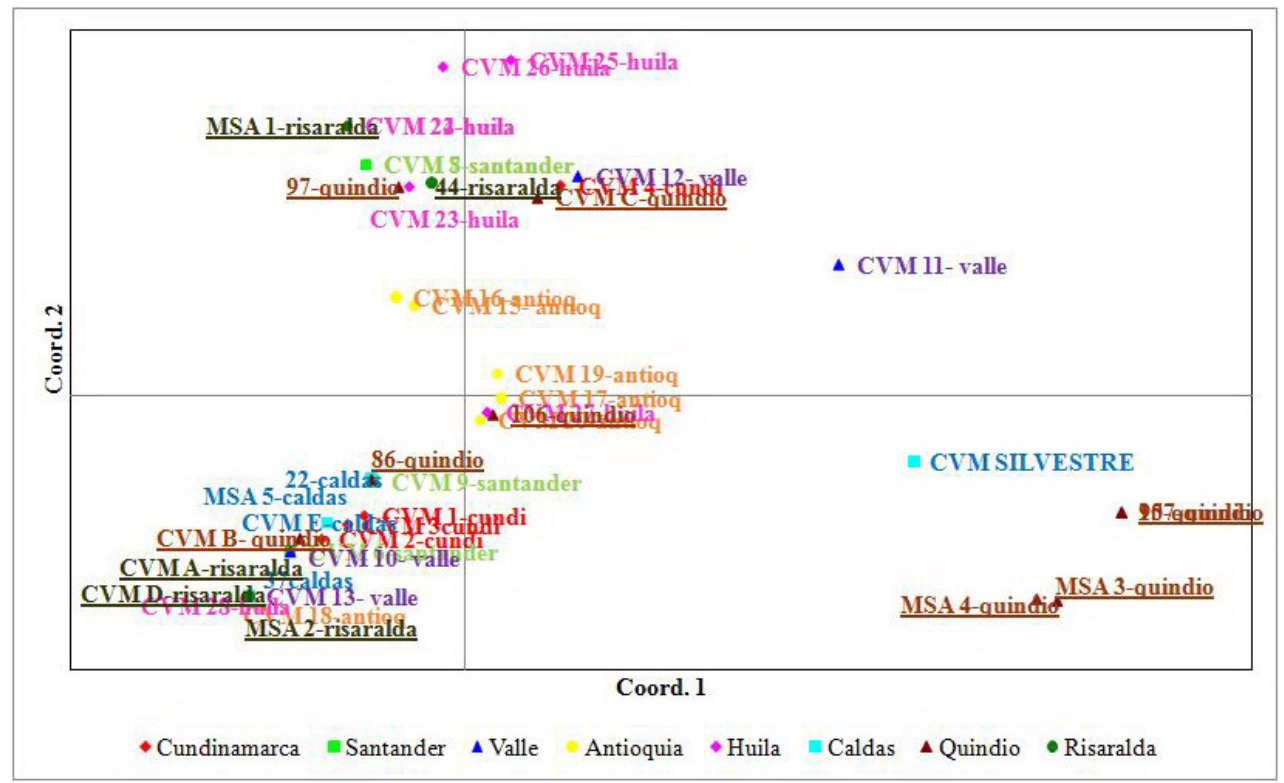

Figure 2. Principal coordinates analysis based on Nei's genetic distance for Rubus genotypes.

The highest $H_{\mathrm{E}}$ values occurred in Valle del Cauca, Quindío and Caldas populations. The values obtained in the current study were compared with those obtained by Marulanda et al. (2007). The heterozygosity values were higher in this study because a larger number of microsatellites and loci for blackberries and red raspberries, developed by Graham et al. $(2002,2004)$, were used; these turned out to be highly polymorphic and informative (Table 2).

Graham et al. (2002) evaluated 50 genotypes belonging to several highly differentiated Rubus species, using 10 microsatellite sequences derived from $R$. idaeus. From 7 to 16 alleles were obtained per locus. The $H_{\mathrm{O}}$ values ranged between 0.52 and 0.91 , whereas the $H_{\mathrm{E}}$ values were between 0.63 and 0.91 . These values are very similar to those obtained in the present study, which evaluated three Rubus species and 45 wild and cultivated genotypes, apparently more closely related because of their distribution in a smaller geographical area (Figure 2).

In studies carried out with European accessions of Rubus, using the SSRs developed by Graham et al. $(2002,2004)$, Badjakov (2007) found $H_{\mathrm{E}}$ values that ranged from 0.2916 at the locus Rubus $98 \mathrm{~d}$ to 0.666 at the locus Rubus $76 \mathrm{~b}$, with an average value of 0.4722 for all genotypes and loci. The mean heterozygosity values in Colombian Rubus accessions, using the same SSRs as Badjakov (2007), were 0.548 for $H_{\mathrm{E}}$ and 0.919 for $H_{\mathrm{O}}$ at the locus Rubus 76b, and 0.534 for $H_{\mathrm{E}}$ and 0.878 for $H_{\mathrm{O}}$ at the locus Rubus 98d (Table 2). The heterozygosity values for the Bulgarian Rubus accessions were lower than those obtained for Colombian Rubus accessions, implying a low heterozygosity in the accessions used in Badjakov's study (2007). The opposite occurred with Colombian Rubus, with the foregoing evidence of higher heterozygosity in the Colombian Rubus germoplasm analyzed. Analysis of molecular variance (AMOVA) showed $90 \%$ variability within populations and $10 \%$ variation between populations. These data agree with those observed in the principal coordinates analysis, where variation is mostly attributed to individuals. 


\section{CONCLUSIONS}

Using microsatellites from other Rubus species has proven to be a very useful strategy to differentiate between wild and cultivated $R$. glaucus genotypes, as well as between thorny and thornless cultivars.

Based on genetic distances, the grouping of genotypes does not depend on their sites of origin. The thornless genotypes from Quindío were separated from the rest of the groups, whereas the thornless genotypes from Risaralda were also placed in different genetic groups, showing important variability among them.

The dendrogram shows that the similarity among cultivated $R$. glaucus materials is quite high, almost $90 \%$, with some materials even showing $100 \%$ similarity.

AMOVA showed a higher variability between genotypes than between populations, which agrees with the results obtained in the principal coordinates analysis.

\section{ACKNOWLEDGMENTS}

Research supported by the Governor's Office of the Department of Risaralda and the Colombian Ministry of Agriculture and Rural Development. We are grateful to the blackberry farmers of Risaralda. Our sincere thanks also go to Juliana Arias Villegas for planning and managing the project and to all laboratory and nursery staff of the Biodiversity and Biotechnology Research Group, and the Universidad Tecnológica de Pereira.

\section{REFERENCES}

Aguilar SB (2006). Caracterización de la Variabilidad Genética de Rubus glaucus en el eje Cafetero Utilizando AFLP. Master's thesis, Universidad Tecnológica de Pereira-Universidad del Quindío-Universidad de Caldas.

Amsellem L, Dutech C and Billotte N (2001). Isolation and characterization of polymorphic microsatellite loci in Rubus alceifolius Poir (Rosaceae), an invasive weed in La Reunion Island. Mol. Ecol. Notes 1: 33-35.

Badjakov IK (2007). Program on Euroberry Research: From Genomics to Sustainable Production, Quality and Health. STSM Scientific Report, Sofia, Bulgaria.

Castillo NRF (2006). Fingerprinting and Genetic Stability of Rubus Using Molecular Markers. Master's thesis, Oregon State University, Corvallis.

Cordeiro GM, Taylor GO and Henry RJ (2000). Characterisation of microsatellite markers from sugarcane (Saccharum sp.), a highly polyploid species. Plant Sci. 155: 161-168.

Dice LR (1945). Measures of the amount of ecological association between species. Ecology 26: 295-302.

Doyle JJ and Doyle JL (1990). Isolation of plant DNA from fresh tissue. Focus 12: 13-15.

Flores NR, Reed BM, Graham J, Fernandez-Fernandez F, et al. (2010). Microsatellite markers for raspberries and blackberries. J. Am. Soc. Hortic. Sci. 135: 271-278.

Graham J, Smith K, Woodhead M and Russell J (2002). Development and use of simple sequence repeat SSR markers in Rubus species. Mol. Ecol. Notes 2: 250-252.

Graham J, Smith K, MacKenzie K, Jorgenson L, et al. (2004). The construction of a genetic linkage map of red raspberry (Rubus idaeus subsp. idaeus) based on AFLPs, genomic-SSR and EST-SSR markers. Theor. Appl. Genet. 109: 740749.

Hall HK (1990). Blackberry breeding. Plant Breed. Rev. 8: 249-312.

Jennings DL and Ingram R (1983). Hybrids of Rubus parviflorus (Nutt.) with raspberry and blackberry, and the inheritance of spinelessness derived from this species. Crop Res. 23: 95-101.

Marulanda ML and López AM (2009). Characterization of thornless Rubus glaucus in Colombia. Can. J. Pure Appl. Sci. 3: 875-885.

Marulanda ML, López AM and Aguilar SB (2007). Genetic diversity of wild and cultivated Rubus species in Colombia using AFLP and SSR markers. Crop Breed. Appl. Biotechnol. 7: 242-252. 
Nei M (1978). Estimation of average heterozygosity and genetic distance from a small number of individuals. Genetics 89: 583-590.

Peakall R and Smouse PE (2006). GenAlEx 6: Genetic analysis in Excel. Population genetics software for teaching and research. Mol. Ecol. Notes 6: 288-295.

Skirvin RM, Motoike S, Coyner M and Norton MA (2009). Rubus spp. Cane Fruit. In: Biotechnology of Fruit and Nut Crops (Litz RE, ed.). Cabi Publishing, Cambridge, 566-583.

Tessier C, David J, This P, Boursiquot JM, et al. (1999). Optimization of the choice of molecular markers for varietal identification of Vitis vinifera L. Theor. Appl. Genet. 98: 171-177.

Thompson MM (1997). Survey of chromosome number in Rubus (Rosaceae: Rosoideae). Ann. Missouri Bot. Gard. 84: $128-164$. 